\title{
Cultural and territorial vitality services play a key role in livestock agroecological transition in France
}

\author{
Jean Beudou ${ }^{1,2}$ • Guillaume Martin ${ }^{2}$ Julie Ryschawy ${ }^{2,3}$
}

Accepted: 15 June 2017 / Published online: 8 August 2017

(C) INRA and Springer-Verlag France SAS 2017

\begin{abstract}
In France, researchers and public policy makers are calling for the agroecological transition of livestock. This transition is facing technical, economic, social, and cultural obstacles. Whereas technical obstacles are extensively studied, other categories remain little studied despite their potential role in agroecological transition of livestock. This article aims to analyze the livestock cultural and territorial vitality (dis)services perceived by local actors on two distinct French territories and to understand how these services could act as levers for the agroecological transition of livestock. To do so, we interviewed 45 local actors from the livestock sector and local rural development in two French territories: Aubrac (24) and Pays de Rennes (21). We conducted inductive content analyses to draw on interviewees' perceptions and link the cultural and territorial vitality services identified to the agroecological transition of livestock. Our work revealed 20 cultural and territorial vitality services that can be organized into 11 categories ( 7 categories of cultural services and 4 categories of territorial vitality services). Among the 11 cultural services, cultural landscapes linked to livestock and gastronomy heritage were the most cited. Among the nine territorial vitality services, the contribution to social bonds on the territories was the most cited. Here, we showed for the first time that the prioritization of cultural and territorial vitality services were different between the territories studied. Emblematic cow
\end{abstract}

Julie Ryschawy

julie.ryschawy@toulouse.inra.fr

1 AgroParisTech, Museum National d'Histoire Naturelle, 75005 Paris, France

2 INRA, UMR, 1248 AGIR, F-31326 Castanet Tolosan, France

3 Université de Toulouse, INP, ENSAT, UMR, 1248 AGIR, F-31326 Castanet Tolosan, France breed, food know-how, and quality products were more important in Aubrac, whereas territorial vitality services such as on-farm jobs and social bonds linked to livestock were more cited in the Pays de Rennes. Such methodological approach allowed us to highlight and prioritize the different cultural and vitality services, which need to be supported by public policy and translated into action.

Keywords Agroecology $\cdot$ Livestock farming $\cdot$ Ecosystem services $\cdot$ Multifunctionality

\section{Introduction}

Researchers and public policy makers are calling for an agroecological transition of agriculture, particularly of livestock farming (Bonaudo et al. 2013; Guillou et al. 2013). We consider the agroecological transition as a transformation towards sustainable agriculture (Gliessmann 1988) and food systems engaged beyond the farm level, namely considering agroecology territories (Wezel et al. 2016). Any analyses of agroecological transition should thus consider the evolution of farming practices, the conservation of environment, and the development of embedded food systems. Still, the agroecological transition is mainly seen as a way to limit the negative impacts of farming on the environment without compromising farm economics (Duru et al. 2015; Guillou et al. 2013; MAAF 2012). Despite some recent changes in the concept of agroecology territories (Wezel et al. 2016), research orientations tend to neglect the social dimension of agroecology that is particularly important for European livestock (Oteros-Rozas et al. 2014; Rodríguez-Ortega et al. 2014). The increasing use of the ecosystem service (ES) concept applied to agroecosystems (Barnaud and Antona 2014; Huang et al. 2015) strengthens this tendency to overlook social aspects. 
The most commonly used ES assessment methods are predominately quantitative and therefore frequently lead to neglect social dimension of livestock systems (Barnaud and Antona 2014; Chan et al. 2012). Only easily quantifiable services are considered such as the employment rate, the "time required and/or arduousness of work" (Guillou et al. 2013). Yet, the social dimension of livestock, including territorial vitality and cultural identity, can constitute obstacles or levers towards the agroecological transition of livestock beyond often-mentioned technical and organizational issues (Duru et al. 2015; Ryschawy et al. 2015).

In this article, we focus on the "(dis)services provided by livestock to society" (Ryschawy et al. 2015). These are "positive (or negative) contributions of livestock farming to society from the farm to the territorial level," categorized into cultural and territorial vitality services. Due to the lack of data available, their quantification of these categories of social services is often limited to the number of jobs created by livestock for the territorial vitality services and to the number of qualitylabeled products and local breeds for the cultural identity services (Ryschawy et al. 2015). These approaches are not satisfactory as these services involve complex interactions between livestock and society at the food system level and can thus hardly be assessed with quantitative methods. This article aims at (1) analyzing the importance of cultural and territorial vitality (dis)services for local actors on two distinct French territories and (2) discussing how societal demand for these services can be an obstacle to, but also a lever for the agroecological transition of livestock farming systems.

\section{Materials and methods}

\subsection{Conceptual framework: services provided by livestock}

In this study, following Ryschawy et al. (2015), we adapted the definition of ecosystem services by Costanza et al. (1997) to livestock systems by considering goods and services provided by livestock farming to society. We thus adopted a broader view of the ecosystem service concept than in the Millennium Ecosystem Assessment (2005) by extending the categories of "goods and services to consider the territorial vitality and by focusing on the interrelationships between livestock farming and society" (Zhang et al. 2007). We thus adopted the categories of Social Environmental Economic Goods and Services (SEEGS) defined by Lynch et al. (2014) and applied by Ryschawy et al. (2015) to services provided by livestock farming to society: (i) provisioning services refer to the food products; (ii) environmental services consider the biophysical processes providing benefits, such as biodiversity maintenance, climate regulation, and water purification; (iii) cultural services are recreational, esthetic, and heritage benefits; and (iv) territorial vitality services refer to rural community vitality and employment. Our research is focused on the last two categories of services that have received little attention from research. Finally, as these two categories are clearly linked to the impact of livestock farming beyond the farm scale, we consider the whole food system scale from production to consumption (Francis et al. 2003). By opposition, when negative contributions of livestock were mentioned on the cultural or territorial vitality dimensions, it was considered as a disservice. For instance, some conflicts between livestock farmers and their neighbors linked to noise or smelling were considered as cultural disservices.

\subsection{A qualitative method with semi-structured interviews}

We chose a qualitative approach was to collect the perceptions of local actors regarding cultural and territorial vitality services. We were strongly inspired by ES socio-cultural assessment methods (Oteros-Rozas et al. 2014; Rodríguez-Ortega et al. 2014). We chose to use a qualitative survey approach with semi-structured interviews, which permits interviews to be organized around the topics studied without restricting the contents of survey responses (Miles and Huberman 1984). Semistructured interviews provide reliable, comparable qualitative data to get a "practical understanding" of stakeholders' knowledge, intentions, and actions (Lugnot and Martin 2013).

The detailed interview guide was designed to collect as much information as possible on cultural and vitality services without mentioning this concept directly. It leaves space to the interviewee in constructing an answer reflecting his ideas and opinions. The first part of the interview consisted in the introduction by the interviewee of his farm, its history, and his/her role in this farm. A second part aimed at understanding stakeholders' representations of the quality of life in their territory, and how livestock contributed to this quality. The third and fourth parts dealt explicitly with, respectively, the cultural and vitality services and disservices, that stakeholders associated with livestock. A last part was dedicated to the relations between cultural and vitality services provided by livestock in the case-study area. Interviews lasted around $2 \mathrm{~h}$ and were carried out during spring and summer 2015. All the interviews were recorded.

\subsection{Sampling strategy}

In keeping with the case-study research approach (Eisenhardt 1989), we chose to interview diverse actors rather than a statistically representative sample of individuals from the territories studied. Our aim was to obtain a diversity of actor situations (mainly in terms of function exerted in the territory) 
from which we expected diverse views of the different (dis) services studied. Indeed, the hypothesis linking the diversity of situations and the diversity of representations is often verified. As our entry point was on how cultural and vitality services can contribute to the agroecological transition of livestock, we focused first on stakeholders in the livestock sector as they can reveal if the provision of these services can influence their practices towards the agroecological transition of livestock. Still, in line with Wezel et al. (2016), we consider that a great diversity of stakeholders should be considered beyond just farmers and consumers. We thus added actors that were indirectly linked to livestock but that were influenced by livestock in their actions or had an influence on livestock through their actions. In accordance with the case-study research approach (Eisenhardt 1989), we continued to conduct interviews as long as new information and points of view emerged, what could contribute to explain the unbalancing of the sample.

Following previous strategies implemented in other contexts (Lamarque et al. 2011; Oteros-Rozas et al. 2014; Rodríguez-Ortega et al. 2014) and based on our expertise and suggestions by the first interviewees, we interviewed actors concerned with the cultural and vitality (dis)services provided by livestock farming. The actors interviewed (Table 1) are belonging to the following categories for the livestock sector:

- Livestock farmers, directly contributing to cultural and vitality (dis)services through their activity (six in each territory)

- Livestock supply chain representatives and advisory services, as they depend on livestock farming to maintain their production units contributing to vitality services and can contribute to the vitality of livestock farming by supporting farmers in developing technical and economic efficiency (eight in Aubrac and six in Pays de Rennes)

Concerning the actors that were indirectly linked to livestock, we interviewed:

- Policy makers (two in Aubrac, four in Pays de Rennes) acting through the development of incentives and regulations leading to develop or reduce cultural and vitality (dis)services,

- Actors of the tourism sector (e.g., employee of the local tourist office; two in Aubrac, one in Pays de Rennes) as they build upon cultural services to develop their offer (e.g., cultural events, guided tours),

- Food and local artisans (three in Aubrac, one in Pays de Rennes) as they contribute to the maintenance of cultural services and the development of vitality services by processing agricultural products and selling the resulting food products or developing their business linked to local livestock traditions,

- Members of associations promoting cultural and natural heritage (three in Aubrac, three in Pays de Rennes) that are especially preoccupied by the maintenance of cultural services.

\subsection{Case-study territories}

Following Ryschawy et al. (2017), we studied two contrasting high livestock density French territories located (Fig. 1), where livestock farming plays a key role in territorial development planning. In line with previous study on this topic, we expected that these territories would be the scene of contrasting cultural and vitality services. The Aubrac plateau area is located in an area where livestock provides a "multifunctional" bundle of services, with provisioning, territorial vitality, environmental and cultural services provided at approximately the same level. This bundle was associated to grasslandbased ruminant production. On the contrary, the Pays de Rennes was located in an area where livestock provides a "provisioning and vitality" bundle, related to high levels of food provisioning and rural vitality services but to environmental disservices.

The first case-study territory was the Aubrac plateau (Fig. 2), which extends across the French departments of Aveyron, Cantal, and Lozère. Aubrac has a low population density. The local economy is organized around agriculture, which represents $25 \%$ of jobs. Aubrac is characterized by extensive (i.e., with low stocking rates and low production per animal) grassland-based upland cattle (mainly beef) farming based on specific breed (Aubrac cattle) and practices (transhumance, grass-based feeding) and quality-labeled, well-developed products (Aubrac beef, Laguiole cheese). Furthermore, efforts to establish a Regional Nature Park where livestock farming would play a major role have been underway in the area for several years.

The second case-study territory was Pays de Rennes, located in the French department of Ille-et-Vilaine, Brittany. In contrast with Aubrac, this territory is densely inhabited as it includes the main city of the Brittany region. Livestock productions are very diverse (poultry, pigs, dairy, and beef cattle) and intensive (i.e., with high stocking rates and high production per animal). Land use is much heterogeneous than in Aubrac with higher percentages of maize and cereal cropping associated to lower percentages of grasslands and forests. Livestock production benefits from closely integrated supply chains. Moreover, Pays de Rennes has developed a strong agricultural project around a "Local Agriculture Program" with a strong focus on livestock farming. For instance, this program proposes actions to save agricultural land against 
Table 1 Profile of individual actors interviewed on their perceptions of cultural and vitality serviced provided by livestock on the two territories studied

\begin{tabular}{lcc}
\hline & First territory: Aubrac & Second territory: Pays de Rennes \\
\hline Actors of the livestock sector & 14 & 14 \\
Livestock farmers & 6 & 6 \\
Sector representatives and advisory services & 8 & 6 \\
& 10 & 9 \\
Actors indirectly related to livestock & 2 & 4 \\
Local governments & 2 & 1 \\
Tourism actors & 3 & 1 \\
Food and cultural artisans & 3 & 3 \\
Cultural and natural heritage associations & 24 & 21 \\
Total & & \\
\hline
\end{tabular}

urbanization, to preserve the bocage landscape and to develop local food systems.

\subsection{Data analyses}

We used inductive content analysis method (Elo and Kyngäs 2008) to process the data collected in the semi-structured interviews. We assumed that specific ideas or theories can directly come from sources other than the quantitative data (Glaser and Strauss 1967). Inductive analyses could be defined by opposition to deductive analyses as the theory is developed on the basis of the synthetic view of the data but not predefined and tested. Inductive content analyses are a combination of two approaches, content and induction analyses. Inductive content analyses enabled us to develop a synthetic view of the services under study. This process may result in new knowledge, insights, and representations of facts. We chose an inductive approach to free ourselves of preconceived ideas. We used open coding (Elo and Kyngäs 2008), first selecting relevant information from sentences and sentence fragments taken from our interviews. We used this information to create sub-categories regrouped into main categories to reduce the number of sub-categories by merging those that are similar. For instance, an actor saying "we often

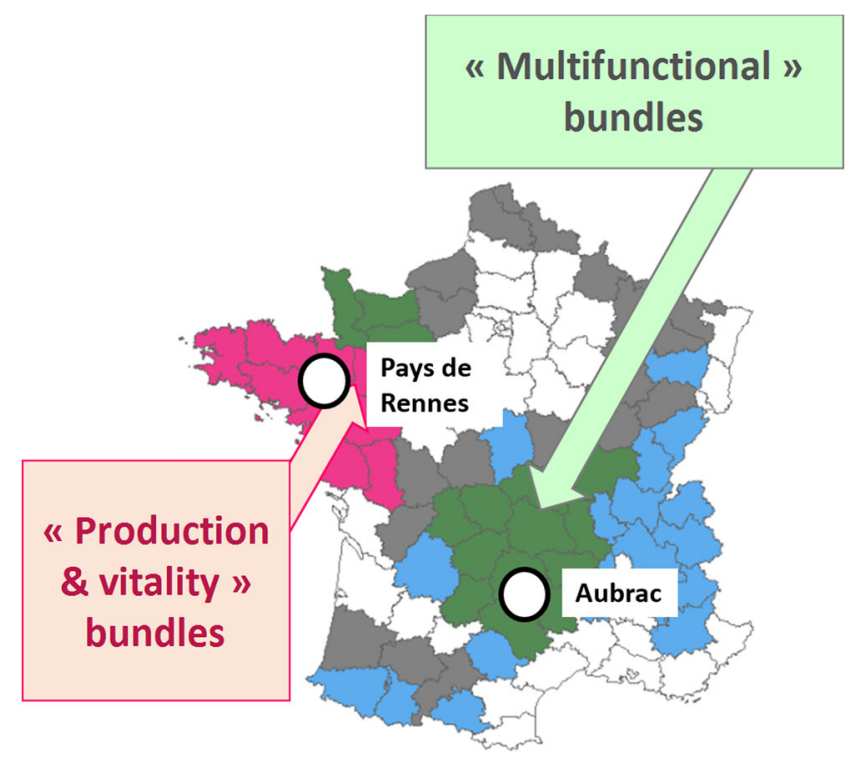

Fig. 1 Geographical location of the two case-study areas as regards to the typology of service bundles provided by French livestock (Ryschawy et al. 2017). The Aubrac plateau area is located in an area where livestock provides a "multifunctional" bundle of services, with provisioning, territorial vitality, and environmental and cultural services provided at approximately the same level. This bundle was associated to grassland-based ruminant production. On the contrary, the Pays de Rennes was located in an area where livestock provides a "provisioning and vitality" bundle, related to high levels of food provisioning and rural vitality services but to higher level of environmental disservices. These two territories display major differences in surface area (1145 vs. $2282 \mathrm{~km}^{2}$ in Pays de Rennes and Aubrac, respectively), altitudinal range (20-74 vs. $250-1469 \mathrm{~m}$ asl), population size (493,193 vs. 33,318 inhabitants), in the types of livestock productions (dairy and beef cattle, pigs and poultry vs. dairy and beef cattle), in land use by agriculture ( $40 \%$ of grasslands and 5\% of forests vs. nearly all land occupied by grasslands and forests), and in the role of agriculture in the local economy and labor market ( 0.5 vs. $25 \%$ of jobs) 

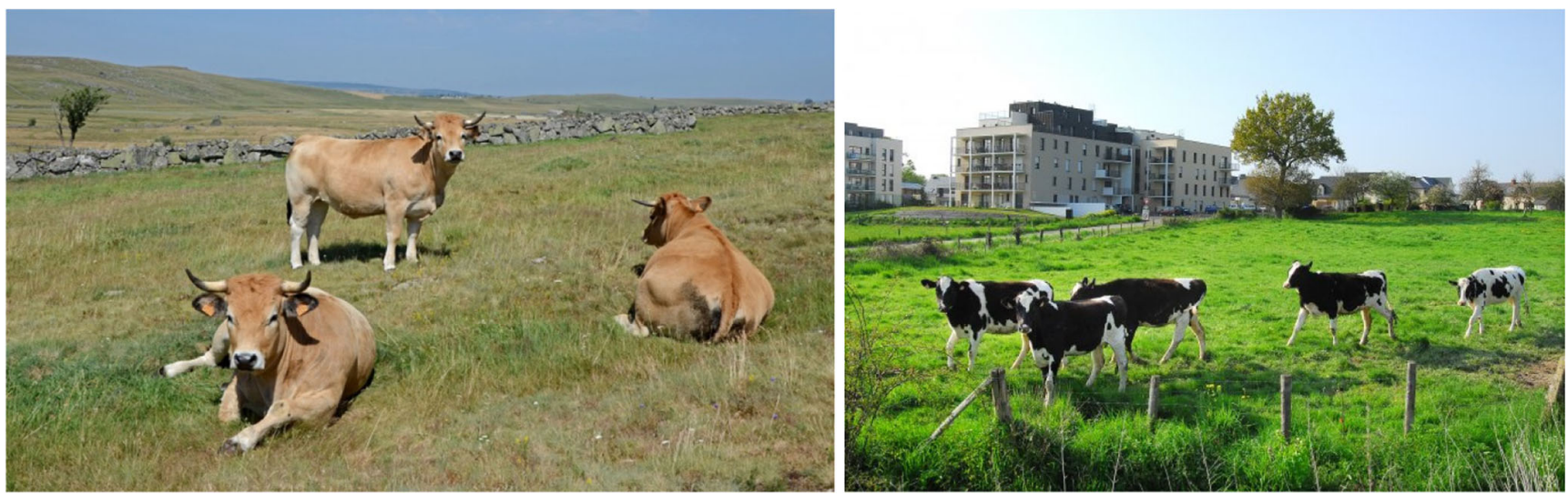

Fig. 2 Photographs illustrating the two contrasted case-study areas. On the left is the view of the typical patrimonial Aubrac livestock farming landscape considered as a cultural service: the natural grasslands bordered by low dry-stone walls and Aubrac cows (photo credit: Pline (personal work) [CC BY-SA 3.0 (http://creativecommons.org/licenses/by-sa/3.0)],

consider that a breed is a territory" would be linked to a subcategory called "emblematic and symbolic breed" within the cultural service category.

We then sought for pieces of stakeholders' discourses that referred to changes in agricultural practices and systems being impeded by the conservation of some cultural and territorial vitality services. We interpreted these services as opportunities and constraints towards the development of an agroecological transition of livestock farming. For instance, the quotation "[farmers] are moving towards higher quality and greater awareness of environmental considerations" was considered as an opportunity for livestock farmers to move towards agroecology and to improve their image for society, by including consumers' expectations in the reasons and motivations underlying their transition.

\section{Results and discussion}

\subsection{Cultural services have contrasted weight among territories}

\subsubsection{Common features: landscape-related services are crucial for local actors}

Analyzing the interviews allowed us to describe seven main cultural service categories (Table 2) that were highlighted in the two territories studied. Landscape-related services hold considerable importance on the two territories (23 actors citing these services in Aubrac and 17 in Pays de Rennes). According to nearly all actors, landscapes shaped by livestock farming are "cultural" because they undeniably contribute to each territory's identity. The grasslands and hedgerows maintained by livestock farmers are the foundations of both the bocage areas in Pays de Rennes and the open grassland via Wikimedia Commons). On the right is the view of the typical patrimonial Pays de Rennes livestock farming landscape considered as a cultural service: pastures are occupied by Prim'Holstein heifers next to housing (photo credit: Marc Rapillard)

dominated plateaus of Aubrac. A manager at a Pays de Rennes urban planning agency said that "Bocage is an emblem here," while a livestock farmer in Aubrac remarked that "we have magnificent landscapes, which are maintained byand only by-livestock farmers."

\subsubsection{Aubrac: cultural services at the crossroad between authenticity and modernization of local breed and products}

In Aubrac, the "animal landscape" constituted by the presence of herds is important too, provided that the herds are composed of Aubrac breed cattle (eight actors cited the "animal" landscape). In the view of one livestock farmer, "the area without the breed, this would not do." The Aubrac breed is seen as a basic landscape element because it is seen as an indisputable and crucial foundation of the territory's identity (the local emblematic breed was cited by 16 local actors). As a heritage association representative said, "We do not know if it was the breed [Aubrac breed] that forged the territory or if it was the territory that forged the breed, but today, the one cannot exist without the other." Still, some actors mentioned that "the current Aubrac breed has been genetically selected towards intensification of production and is now less suited to traditional breeding." Moreover, since the 1980s, the dairy cooperative has allowed farmers to produce milk with Simmental cows. Current feeding practices use high amounts of concentrates to produce milk and do not correspond to the nature-based image of Aubrac highlighted for tourists. This modernization of practices allowed to some producers to increase production level but is creating conflicts with farmers having a more traditional vision of local livestock.

The "built landscape" linked to livestock tradition also appears to be important. A local council representative noted that "Burons [mountain huts] have become the basic elements that 
Table 2 Categorization and listing of cultural services perceived by actors interviewed in the two territories studied: Aubrac and Pays de Rennes

\begin{tabular}{|c|c|c|c|}
\hline $\begin{array}{l}\text { Sub-category of } \\
\text { cultural services }\end{array}$ & Cultural services mentioned & $\begin{array}{l}\text { Number of actors } \\
\text { mentioning the } \\
\text { service in Aubrac }\end{array}$ & $\begin{array}{l}\text { Number of actors } \\
\text { mentioning the } \\
\text { service in Pays de } \\
\text { Rennes }\end{array}$ \\
\hline \multirow[t]{3}{*}{ Cultural landscapes } & $\begin{array}{l}\text { Characteristic "vegetation" landscape } \\
\text { elements associated with livestock }\end{array}$ & 12 & 1 \\
\hline & $\begin{array}{l}\text { Characteristic "animal" landscape } \\
\text { elements associated with livestock }\end{array}$ & 8 & 11 \\
\hline & $\begin{array}{l}\text { Characteristic "architectural" } \\
\text { landscape elements associated with } \\
\text { livestock (wood walls, old } \\
\text { buildings, ...) }\end{array}$ & 3 & 5 \\
\hline Gastronomy heritage & $\begin{array}{l}\text { Specific livestock products relating to } \\
\text { local heritage }\end{array}$ & 17 & 9 \\
\hline Emblematic breeds & Emblematic and symbolic breeds & 16 & 3 \\
\hline \multirow[t]{2}{*}{ Cultural know-how } & $\begin{array}{l}\text { Know-how associated with local } \\
\text { production modes }\end{array}$ & 9 & 0 \\
\hline & $\begin{array}{l}\text { Know-how associated with local } \\
\text { processing modes }\end{array}$ & 6 & 0 \\
\hline Heritage festivals & $\begin{array}{l}\text { Festive events associated with heritage } \\
\text { style livestock farming }\end{array}$ & 3 & 0 \\
\hline $\begin{array}{l}\text { Relationship with } \\
\text { "nature" }\end{array}$ & $\begin{array}{l}\text { Close relationship with the living } \\
\text { world specific to livestock }\end{array}$ & 12 & 2 \\
\hline Educational value & $\begin{array}{l}\text { Visits and communications around } \\
\text { livestock farming }\end{array}$ & 6 & 14 \\
\hline $\begin{array}{l}\text { Number of actors } \\
\text { mentioning at } \\
\text { least one cultural } \\
\text { service }\end{array}$ & & 22 & 19 \\
\hline $\begin{array}{l}\text { Number of actors } \\
\text { interviewed }\end{array}$ & & 24 & 21 \\
\hline
\end{tabular}

make our territory distinctive" (three actors citing this service). In Aubrac, the gastronomy heritage associated with livestock, whether involving raw products (Aubrac beef) or processed foods (aligot [melted cheese blended into mashed potatoes], Laguiole cheese, charcuterie), is a major component of Aubrac identity (cited by 17 actors). As one representative of a heritage association said, "It is the landscape, the breed [Aubrac breed], and the products [associated with livestock] that make the territory." These cultural markers exist alongside traditional Aubrac know-how beyond livestock farming. These breeding and processing skills shape the gastronomy heritage (knowing how to fatten animals, how to make cheese, ...). This traditional way of farming is not the only way of producing now as animals could be sent to Italy to be fattened. This know-how is still highlighted at different festive events (for example, animal competitions, transhumance), which are seen by actors as part of their heritage (cited by three actors). The link between animals and livestock keepers is strong in the area (cited by 10 actors). Still, the nondynamic aspects of the local traditional way of producing is seen as cultural disservice by seven actors, considering in particular the risk to maintain old-fashioned way of producing "only for the touristic show" and the risk of traditional management on biodiversity when grasslands are overgrazed for instance.

\subsubsection{Pays de Rennes: cultural services are a way to reconnection between livestock farming and society}

In Pays de Rennes, the presence of livestock is important in the local identity, in particular in the landscape (cited by 17 actors on 21). Still, cultural services are not associated with a specific gastronomy heritage linked to traditional products, specific local breeds (only three citing), traditional know-how, or heritage events (not cited by the local actors). Local livestock farming was strongly linked to cultural identity in the past, but industrialization of agriculture yielded disconnection for most local actors. According to them this is due to the highly integrated, productive, standardized livestock farming structured around supply chains. For one livestock farmer, local agriculture "has very rapidly taken on an industrial character and has lost, no doubt, quite a bit of the cultural diversity that existed."

Still, the Pays de Rennes is structured as an archipelago with the city of Rennes and little cities around interlinked with rural areas. Thus, local actors explained that they are in contact with animals when they graze or at least see farm buildings. For them, livestock farming has an educational value about the interplay 
between animals, "nature," and livestock farmers (mentioned by 14 actors). Thus, animals could play an educational role. As one former mayor notes, "livestock farming is by definition embedded with cultural value related to life and living organisms. This is why a live animal is still different from a live plant." Livestock farming is also seen to provide educational services, notably for school children, concerning human relationship with food. Thus, for one local council representative, it is necessary to "allow schoolchildren to grasp this link between what they see on their plates and where it came from" Thus, attracting children on educational farms could favor the reconnection between consumer and food production. Still, noise and smelling due to livestock production is cited by five actors as a main cultural disservice.

\subsection{Two different models of territorial vitality services}

\subsubsection{Common features: livestock is creating employment in both territories}

Four main categories of territorial vitality services were highlighted (Table 3). Stakeholders in the two territories distinguish between employment generated by livestock farming directly (on farms) and indirectly (via input suppliers and supply chains, as well as in support services and research). Actors on the two territories emphasized the importance of livestock farming for rural "life"; it maintains shops, services, and associations on the territories. Social bonds within the community were mentioned by 5 actors in Aubrac and 12 in Pays de Rennes. The social bonds between livestock farmers were mentioned by nine actors in Aubrac. As one local council representative noted, "livestock farmers avoid the development of bedroom cities." Moreover, the landscapes and tight knit territorial fabric maintained by livestock farmers contribute to the attractiveness of the area as a place to reside. In Pays de Rennes, territory has given itself the image of "urban country living." Last but not least, as a Chamber of Agriculture representative explained, "Farmers are often involved in communes, associations, and economic activities because they have side businesses."

\subsubsection{Aubrac: cultural and vitality services are strongly interlinked}

In Aubrac, the actors also emphasized how the "authentic" image of livestock farming can contribute to the image and attractiveness of the territory. In particular, 15 actors mentioned the contribution of livestock to tourism appeal in Aubrac. For one butcher, "That is what people like: authenticity [...] When one mentions the word 'Aubrac,' that's what people hear." A special feature highlighted by actors is the contribution of cultural services related to gastronomy,
Table 3 Categorization and listing of territorial vitality services perceived by actors interviewed in the two territories studied: Aubrac and Pays de Rennes

\begin{tabular}{|c|c|c|c|}
\hline $\begin{array}{l}\text { Sub-category of vitality } \\
\text { services }\end{array}$ & $\begin{array}{l}\text { Territorial vitality services } \\
\text { mentioned }\end{array}$ & $\begin{array}{l}\text { Number of actors } \\
\text { mentioning the } \\
\text { service in Aubrac }\end{array}$ & $\begin{array}{l}\text { Number of actors } \\
\text { mentioning the service } \\
\text { in Pays de Rennes }\end{array}$ \\
\hline \multirow{2}{*}{$\begin{array}{l}\text { Employment associated } \\
\text { with livestock farming }\end{array}$} & On-farm jobs & 0 & 7 \\
\hline & Livestock sector jobs & 4 & 3 \\
\hline \multirow[t]{4}{*}{$\begin{array}{l}\text { Contribution to social } \\
\text { bonds on the territories }\end{array}$} & $\begin{array}{l}\text { Social bonding, social } \\
\text { cohesion promoted at the } \\
\text { territorial scale }\end{array}$ & 5 & 12 \\
\hline & $\begin{array}{l}\text { Social bonding between } \\
\text { livestock farmers }\end{array}$ & 9 & 0 \\
\hline & $\begin{array}{l}\text { Maintenance of rural fabric } \\
\text { (schools, services, } \\
\text { shops...) }\end{array}$ & 2 & 0 \\
\hline & $\begin{array}{l}\text { Involvement of livestock } \\
\text { farmers in associations } \\
\text { and local government }\end{array}$ & 1 & 0 \\
\hline $\begin{array}{l}\text { Contribution to the } \\
\text { territories' reputation }\end{array}$ & $\begin{array}{l}\text { Role of livestock farming in } \\
\text { the image, attractiveness } \\
\text { of the territory }\end{array}$ & 4 & 3 \\
\hline \multirow[t]{2}{*}{$\begin{array}{l}\text { Contribution to vitality of } \\
\text { tourism }\end{array}$} & $\begin{array}{l}\text { Contribution to tourism } \\
\text { appeal }\end{array}$ & 15 & 3 \\
\hline & Attraction for agrotourism & 3 & 0 \\
\hline $\begin{array}{l}\text { Number of actors } \\
\text { mentioning at least one } \\
\text { territorial vitality service }\end{array}$ & & 21 & 18 \\
\hline $\begin{array}{l}\text { Number of actors } \\
\text { interviewed }\end{array}$ & & 24 & 21 \\
\hline
\end{tabular}


landscapes, cultural know-how, and festive events to the development of tourism. A local NGO representative clearly explained that "Landscape, products, and breed are creating the territory." In the opinion of this local council official, "if Aubrac is focusing its local development efforts more and more on tourism, it is because the presence of herds are now part of consumers' demands and societal expectations." A revealing example of this link to tourism is the success of the Transhumance Festival celebrating the ascent of Aubrac herds to summer mountain pastures. According to one heritage association representative, this festival "generates unbelievable business within a $50 \mathrm{~km}$ radius [...] Every year, over 15,000 people attend the event." This image, linked to a great extent to livestock farming, can furthermore have positive side effects on other economic activities such as craft-knife factories, linked to the traditional livestock system "Laguiole" in the area. Still, the linkage between cultural and vitality services is creating some disservices according to five actors, thinking that this traditional model of production is not adapted to the future. Worries regarding the future economic viability of livestock sector and the decrease in the number of local producers were cited.

\subsubsection{Pays de Rennes: strong livestock sector is creating territorial vitality services disconnected from cultural services}

In Pays de Rennes, the economic sector linked to livestock farming is a source of real pride for most actors of the livestock sector locally (12 actors mentioned the social bonds linked to livestock in the local territory). The socioeconomic development of Brittany was closely linked to the development of the livestock sector, and this could explain this pride. As one local council representative said, "Culturally, there is pride in Breton agriculture [meaning the entire Breton agroindustrial model]." This pride should be understood in the light of the once widespread poverty in Brittany, which remains an undeniable stigma for many of the actors encountered. Post-war modernization and the emergence of the highly productive "Breton model" for agriculture were experienced as a deliverance from this poverty. As an agricultural advisor said, "A livestock farm is creating five livestock-related jobs in the region."

The social bonds engendered by livestock farming were more highlighted in Pays de Rennes than in Aubrac (cited 12 times in Pays de Rennes and 5 in Aubrac). These bonds are formed in different ways: through short marketing channels, communication concerning animal husbandry, festive events, and contact with tourists. On a sub-urban territory, a distance often exists between the urban and rural populations (and thus livestock farmers) despite their geographic proximity. Short marketing channels set up by livestock farmers allow people to come together and contribute to the territory's social cohesion. For one local council representative, short marketing channels are "the primary vector of urban-rural dialogue."

These various territorial vitality services are often used to minimize the negative economic and environmental features of industrialized livestock farming which could incite change. Even if we were not studying in particular environmental dimension, the actors mentioned it. In particular, five actors have mentioned visual and smelling disservices. According to one local council representative, this largely explains why people were and remain "in denial regarding all negative features [of livestock farming]," notably environmental impacts (e.g., nitrate pollution, eutrophication). Some actors expressed territorial vitality disservices such as the economic future of livestock sectors for five actors. The industrial livestockfarming model is currently creating trade-offs between cultural and territorial vitality services. The vitality services are linked to the current industrialized livestock model, whereas the cultural services were more linked to the old traditional way of producing before the 1970s. Some livestock farmers are nostalgic from the rich culture they had before: "Agriculture in Brittany has developed towards production and industrialization and lost part of its rich cultural diversity." Some actors in Pays de Rennes deplored the loss of most cultural services associated with a gastronomy heritage or local breed. Still, consumer demand could favor the development of alternative or niche system that could re-build the link between livestock farming and local actors.

\subsection{Interrelations between cultural and vitality services could act as obstacles or levers for agroecological transitions}

\subsubsection{Better integration of cultural and territorial vitality services is needed to implement agroecological transition}

Our study shows the diversity of cultural and territorial vitality services provided by livestock farming and the importance that they hold for actors on the two territories studied. Further studies should consider the impact of these services on agroecological transition. Neither the research nor public policy worlds can ignore these services when addressing the agroecological transition of livestock farming. To do so would be counterproductive in two ways. First, as our results indicate, social services are important for numerous actors, even those who are not part of the livestock sector. These findings are in line with the concept of agroecology territories developed by Wezel et al. (2016). Second, numerous factors blocking this transition would remain unidentified and therefore difficult to overcome. These blocking factors can be analyzed in terms of "lock-ins" (Geels 2010) impeding an agroecological transition. A lock-in is defined as a situation where a dominant "technology" hinders the development of other "technologies," and therefore of alternative trajectories 
(Geels 2010). A lock-in may have multiple causes: technical, social, cultural, economic, and/or political. In parallel, some services could be considered as opportunities for the agroecological transition of livestock farming. Thus, cultural and territorial vitality services could act in favor or as obstacles for the agroecological transition of livestock farming. Understanding their interrelationships could help unlocking the agroecological transition, considering the bundles of services provided by livestock at a same spatial and temporal level (Bennett et al. 2009; Raudsepp-Hearne et al. 2010).

\subsubsection{Aubrac: synergy between cultural and territorial vitality services could be an obstacle to any transition}

In Aubrac, the livestock sector communicates on a local tradition interlinking the breed, landscape, livestock products, and tourism. The products, whether dairy, meat, or processed foods, make the most of their quality, terroir, and defense of local cultural heritage features. As highlighted by Ryschawy et al. (2017), the local livestock is producing a multifunctional bundle of services, including maintaining of permanent grasslands and enhancing biodiversity. Products are mostly processed and sold directly in cooperatives and craft food shops. The local aim is to defend an emblematic local gastronomy linked to a traditional way of producing. In this way, bonds were formed between producers and consumers, and notably with tourists seeking these special features. Still, fours actors consider that the tradition is hindering any transition of local livestock. For instance, "Aubrac livestock farming practices correspond to a museum the tourists like" that has proved successful in developing territorial vitality services. Despite its advantages, the strong interrelationships between cultural, territorial vitality, and environmental services are creating inertia. Cultural services hold much importance for local actors, because tourists seeking "authenticity" recognized them as contributing to territorial vitality services. These services tend to reinforce livestock actors' attachment to traditional livestock farming. This is why a cheese factory director explained that "dairy production in Aubrac [...] is badly perceived by local people who would like to see farmers milking by hand pure-bred Aubrac cows." Thus, the vitality of tourism in Aubrac creates inertia for the modernization of livestock farming.

This obstacle to modernization is well illustrated by two other examples of local alternative production. For instance, the local label "Fleur d'Aubrac" has been developed for meat. As the Aubrac breed has a bad conformation with respect to slaughterhouses scoring scale, Aubrac cows are crossed with Charolais bulls. The resulting Fleur d'Aubrac meat is better paid to farmers. Still, more imported feed concentrates have to be given to the animals what is not in line with the local tradition of using permanent grasslands and seeking for autonomy. Locally, most actors consider that this is treason to the tradition and even to the consumers that believe buying local pure-breed meat. The label is even criticized for the quality of meat coming from the crossing of the breed and for the inputs needed to feed the animals. A local butcher explained that "With the Fleur d'Aubrac label, they did a wonderful poker play!" Involving more actors on the topic would be needed to really understand the lock-in here, as Stassart and Jamar (2008) on the Blanc-Bleu-Belge breed. Still, our approach allowed us to consider the importance of cultural services here, even if we did not aim at prioritizing social services as regards to economic and environmental ones. A more systemic vision of the food chain would be needed to favor agroecological transition. Another example refers to a livestock farmer producing cheese from ewes rather than from cattle. As ewes were unusual in Aubrac over the last century, she is not supported by communication equivalent to what is done with cattle farmers.

\subsubsection{Pays de Rennes: trade-offs between vitality and cultural services could act as a lever for agroecological transitions}

The difficulties encountered in Pays de Rennes can be explained by numerous lock-ins: political lock-ins through the allocation of public aid, technical lock-ins involving farmers' practices... As explained by (Fernandez et al. 2012), "ecological change cannot happen without social, economic, and political change." In Pays de Rennes, the socio-economic lock-in stemming from uncertainty about the future of jobs directly and indirectly linked to livestock farming appears critical for the agroecological transition. Likewise, it is a socio-cultural lock-in, which is impeding the development of Pays de Rennes' "forgotten local breeds". Still, the maintenance or reintroduction of these breeds would be in line with the development of agrobiodiversity, a historic principle of agroecology (Duru et al. 2015). However, these breeds are symbolic of the impoverished era that preceded the advent of the Breton agricultural model, which is itself seen as a driver of local territorial vitality. Furthermore, like the lock-ins of the Blanc-Bleu Belge sector (Stassart and Jamar 2008), lock-ins are to be found in cultural food consumption habits.

As indicated by a heritage association representative, "We are a tourist region without terroir (locally specific) products. Yet, it is clear that tourist regions need terroir products, everywhere you go, such products are part of the local economy." There is thus a societal demand for cultural services, and to furnish these services, a transition in livestock farming is required towards the emergence of alternative agri-food systems (Fernandez et al. 2012). These systems aim to bring producers and consumers closer together by opposing, in a more or less radical manner, the dominant food system (Allen et al. 2003). Pays de Rennes is marked by the diversity of short marketing channels for livestock products (marketplaces, direct producer-consumer circuits, farm sales, producer shops...). To varying degrees, these initiatives are breaking away from the "Breton livestock farming model," notably characterized by being deeply integrated into agrofood 
industries. These systems also are helping to unlock the dominant agrofood system as they are new niche options aside (Geels 2010). This is still questioning the future options for farmers that do not want to develop short sales.

It was in this way that Pays de Rennes, working with highly productive Breton model poultry farms, developed the "Coucou de Rennes" sector (chicken breed). The brand was created around some dozen producers, and the Coucou de Rennes chicken is today a well-recognized product sought by many renowned chefs. The Pays de Rennes Local Agriculture Program cites this production as an example to promote the development of local sectors projecting the image of the territory. From a technical perspective, Coucou de Rennes production practices break away from conventional farming: a minimum slaughter age of 130 days (instead of 40 days in a conventional system) to favor the development of the product's organoleptic quality, stronger ties to the land (minimal range area $10 \mathrm{~m}^{2} /$ bird), marketing through short channels required... The development of such a sector does not take place without some bumps along the road. According to actors, the development of local breeds in the beef and pork sectors runs up against consumers' taste for lean, tender meat without a pronounced taste. In this case, only a strong territorial dynamic supported by public policies such as the Pays de Rennes Local Agriculture Program, bringing together numerous actors (producers, citizen-consumers, and public authorities), can overcome this type of obstacle and serve as a lever for transition in livestock farming systems.

In Pays de Rennes, both the geographic specificity of the territory (sub-urban area), and the territory's policy aiming to maintain sub-urban livestock farming and bring producers and citizen-consumers closer together, result in certain services being very specific to the area. The services related to education and social bonds hold considerable importance and are demanded by all of the local actors, including livestock farmers. Their development thus is a lever for the agroecological transition of livestock farming, and more broadly of the food system. At a later date, these educational services, and those associated with social bonds, could facilitate the development of other services. According to a local council representative, "by opening up their farms, [farmers] are moving towards higher quality and greater awareness of environmental considerations."

\section{Conclusion}

We analyzed the importance of cultural and territorial vitality (dis)services for 45 local actors on two contrasted French territories, Aubrac and Pays de Rennes. We demonstrated that in both territories, these services were numerous and diverse with 20 services identified that can be refined into 11 categories including gastronomy heritage, cultural landscapes, and contribution to social bonds on the territories. We evaluated the effects of (dis)services as potential lock-ins or opportunities for the agroecological transition of livestock farming in the case-study areas considered. The maintaining of some specific cultural and vitality (dis)services could act as lockins for the agroecological transition of local livestock farming, creating inertia of current traditional livestock in Aubrac. On the contrary, development of cultural services could act as an opportunity for the agroecological transition of livestock farming in Pays de Rennes due to the consumer demand for more locally embedded animal products. Further studies combining cultural and territorial vitality services with provisioning and environmental services would allow (i) the weighting of different services required to orient both research and the public policy arbitrage necessary to steer the agroecological transition and (ii) characterization of synergies and trade-offs between services. Awareness of trade-offs between services could limit the lock-in effect in taking jointly cultural and territorial vitality services into consideration.

Acknowledgements We would like to thank GIS Elevages Demain and in particular the Centre National Interprofessionnel de l'Economie Laitière (CNIEL) for funding this study. We also thank all of the people encountered on the two territories. This work also benefited from the support of the ANR project Tatabox (ANR-13-AGRO-0006).

\section{References}

Allen P, Fitz Simmons M, Goodman M, Warner K (2003) Shifting plates in the agrifood landscape: the tectonics of alternative agrifood initiatives in California. J Rural Stud 19:61-75

Barnaud C, Antona M (2014) Deconstructing ecosystem services: uncertainties and controversies around a socially-constructed concept. Geoforum 56:113-123

Bennett EM, Peterson GD, Gordon LJ (2009) Understanding relationships among multiple ecosystem services: relationships among multiple ecosystem services. Ecol Lett 12:1394-1404. doi:10.1111/j. 1461-0248.2009.01387.x

Bonaudo T, Bendahan AB, Sabatier R, Ryschawy J, Bellon S, Leger F, Magda D, Tichit M (2013) Agroecological principles for the redesign of integrated crop--livestock systems. Eur. J. Agron. 57:43-51

Chan KMA, Guerry AD, Balvanera P, Klain S, Satterfield T, Basurto X (2012) Where are cultural and social in ecosystem services? A framework for constructive engagement. Bio Sci 62:744-756. doi: 10.1525/bio.2012.62.8.7

Costanza R, d'Arge R, de Groot R, Farber S, Grasso M, Hannon B, Naeem S, Limburg K, Paruelo J, O’Neill RV, Raskin R, Sutton P, van den Belt M (1997) The value of the world's ecosystem services and natural capital. Nature 387:253-260. doi:10.1038/387253a0

Duru M, Therond O, Fares M (2015) Designing agroecological transitions: a review. Agron Sustain Dev 35:1237-1257. doi:10.1007/ s13593-015-0318-X

Eisenhardt KM (1989) Building theories from case study research. Acad Manag Rev 14:532-550

Elo S, Kyngäs H (2008) The qualitative content analysis process. J Adv Nurs 62:107-115. doi:10.1016/S0167-8809(03)00152-X 
Fernandez M, Goodall K, Olson M, Mendez E (2012) Agroecol Altern Agrifood Mov in the United States: towards a sustainable agrifood system. J Sustain Agric 37-1:115-126

Francis C, Lieblein G, Gliessman S, Breland A, Creamer N, Harwood R, Salomonsson L, Helenius J, Rickerl D, Salvador R, Wiedenhoeft M, Simmons S, Allen P, Altieri M, Flora C, Poincelot R (2003) Agroecology: the ecology of food systems. J Sustain Agric 22:99118

Geels FW (2010) Ontologies, socio-technical transitions (to sustainability), and the multi-level perspective. Res Policy 39:495-510

Glaser B, Strauss A (1967) The discovery of grounded theory. Aldline, Chicago $271 \mathrm{pp}$

Gliessman S (1998) Agreocology: ecological processes in sustainable agriculture. Ann Arbor Press, Chelsea, Michigan, Etats-Unis

Guillou M, Guyomard H, Huyghe C, Peyraud JL (2013) Le projet agroécologique: Vers des agricultures doublement performantes pour concilier compétitivité et respect de l'environnement-propositions pour le ministre. Agreenium-INRA, Paris

Huang J, Tichit M, Poulot M, Darly S, Li S, Petit C, Aubry C (2015) Comparative review of multifunctionality and ecosystem services in sustainable agriculture. J Environ Manag 149:138-147. doi:10. 1016/j.jenvman.2014.10.020

Lamarque P, Meyfroidt P, Nettier B, Lavorel S (2014) How ecosystem services knowledge 825 and values influence farmers' decision making. PLoS ONE, 9, e107572

Lugnot M, Martin G (2013) Biodiversity provides ecosystem services: scientific results vs. stakeholders' knowledge. Reg Environ Chang 13:1145-1155. doi:10.1007/s10113-013-0426-6

Lynch DH, Sumner J, Martin RC (2014) Framing the social, ecological and economic goods and services derived from organic agriculture in the Canadian context. In: Organic farming, prototype for sustainable agricultures. Springer, Netherlands, pp 347-365

MEA (Millennium Ecosystem Assessment) (2005) Ecosystems and human well-being. In: Biodiversity synthesis. World Resources Institute, Washington $90 \mathrm{pp}$
Miles MB, Huberman AM (1984) Qualitative data analysis: a sourcebook of new methods. SAGE Publications Inc, Beverly Hills

Ministre de l'Agriculture, de l'Agroalimentaire et de la forêt (2012) Le Projet agro-écologique pour la France. Paris, France

Oteros-Rozas E, Martín-López B, González JA, Plieninger T, López CA, Montes C (2014) Socio-cultural valuation of ecosystem services in a transhumance social-ecological network. Reg Environ Chang 14: 1269-1289. doi:10.1007/s10113-013-0571-y

Raudsepp-Hearne C, Peterson GD, Bennett EM (2010) Ecosystem service bundles for analyzing tradeoffs in diverse landscapes. Proc Natl Acad Sci U S A 107:5242-5247. doi:10.1073/pnas.0907284107

Rodríguez-Ortega T, Oteros-Rozas E, Ripoll-Bosch R, Tichit M, MartínLópez B, Bernués A (2014) Applying the ecosystem services framework to pasture-based livestock farming systems in Europe. Animal 8:1361-1372. doi:10.1017/S1751731114000421

Ryschawy J, Tichit M, Bertrand S, Allaire G, Plantureux S, Aznar O, Perrot C, Guinot C, Josien E, Lasseur J, Aubert C, Tchakérian E, Disenhaus C (2015) Comment évaluer les services rendus par l'élevage ? Une première approche méthodologique sur le cas de la France . INRA Productions Animales, 28(1):23-38. http://prodinra. inra.fr/record/305989

Ryschawy J, Disenhaus C, Bertrand S, Allaire G, et al. (2017) Assessing multiple goods and services derived from livestock farming on a nation-wide gradient. Animal. In press

Stassart PM, Jamar D (2008) Steak up to the horns! The conventionalization of organic stock farming: knowledge lock-in in the agrifood chain. Geo J 73:31-44

Wezel A, Brives H, Casagrande M, Clément C, Dufour A, Vandenbroucke P (2016) Agroecology territories: places for sustainable agricultural and food systems and biodiversity conservation. Agr Oecol Sustain Food Syst 40(2):132-144. doi:10.1080/ 21683565.2015.1115799

Zhang W, Ricketts TH, Kremen C, Carney K, Swinton SM (2007) Ecosystem services and dis-services to agriculture. Ecol Econ 64: 253-260. doi:10.1016/j.ecolecon.2007.02.024 